\title{
The blind spot of relationships in consumer markets: the consumer proneness to engage in relationships
}

\author{
Teresa M. Fernandes, Universidade do Porto, Portugal* \\ João F. Proença, Universidade do Porto, Portugal
}

\begin{abstract}
This paper looks at the nature of relationships between consumers and firms, developing a dyadic conceptual model for consumer markets where both parties are taken into consideration. We question whether a relationship is necessarily the preferred state from the customer's perspective or if this is only in the mind of the seller. This topic appears to remain the blind spot of relationships in consumer markets. The empirical data is gathered from interviews and focus group discussions embedded in three cases from banking, mobile communications and retailing services. The paper shows that customers may differ in terms of the types of relationships they require and in how they may want to transact or relate. We conclude that different situations are likely to coexist with different consumers, which makes it hard to establish a general pattern of consumer market relationships.
\end{abstract}

Keywords Relationships, Relationship marketing, Consumer markets

\section{INTRODUCTION}

In the early to mid 1990s, "Relationship Marketing" (RM), became of great interest both to academics and practitioners (Buttle 1996; Sheth and Parvatiyar 2000), becoming "the hot topic of the marketing discipline" (Möller and Halinen 2000, p. 29). Slowly at first and then with a rush unabated, the growing interest in RM brought mature literature and increased recognition of its benefits (Berry 2002). Many marketing academicians accepted RM as the latest gospel and began spreading it faithfully as loyal disciples (O’Malley and Tynan 2000). Often described as "the

*Correspondence details and biographies for the authors are located at the end of the article. 
emperor's new clothes" (Egan and Harker 2005), RM began to dominate the marketing agenda. A paradigm shift in marketing at the expense of four Ps was foreshadowed (Grönroos 2000). Gummesson (2002) replaces the four Ps of transactional marketing by the 30 Rs. Firms started to aim for "share of wallet" instead of market share. Some authors describe the client lifecycle (Palmer and Bejou 1994) and "the marketing ladder of customer loyalty". A brand new vocabulary of "partnerships", "alliances" and "key accounts" showed up.

However, as the dust begins to settle, questions are being asked about how much of RM is reality and how much is pure rhetoric (Fournier, Dobscha and Mick 1998; Shrivastava and Kale 2003). Much of the research to date appears highly selective and frequently designed to support an often consultant-based perspective. In fact, RM may be easier said than done (Egan 2001). The basic values of the manipulative marketing mix theory seem to remain: technology is only being used to make it more difficult for the customer to "slip the hook", much like "the fisherman's relationship to the fish" (Gummesson 2004, p. 9). According to Egan (2003 p. 147), RM seems to be emerging as a general "umbrella philosophy" with numerous variations, currently "enjoying" the unusual status of being both an overused and underdeveloped concept. For instance, a content analysis of 117 different sources done by Harker (1999) produced as many as 26 substantial definitions of RM. Much of what has been done in RM in the past has taken for granted its meaning. But what are the relationships behind RM? Do we all share the same understanding of it? Are relationships alike whatever the market (Zolkiewski 2004)? The attempt to create "individualised" relationships with a massive market, where no close interactions are likely to occur appears to be misplaced. Perhaps it is the allure of such a theory that tempted scholars to import variables from the business domain with impunity, whatever little emphasis there is on consumer markets (Shrivastava and Kale 2003) and to call it "relationship" marketing. Some researchers are already trying to prevent the premature death of RM, due to the over-use, misuse and even abuse of the term. In fact, the term RM, although very popular, seems to neglect the nature of relationships. Next, we will go on by looking at the nature of relationships in consumer markets and question whether a relationship is necessarily the preferred state from the customer's perspective.

\section{RELATIONSHIPS IN CONSUMER MARKETS?}

Relationships are not wholly applicable and present considerable barriers in consumer markets (O’Malley and Tynan 2000), where there are too many customers, with too many variations, often spending relatively small sums. The sheer size of these markets, the lack of consumer interest in a "real" relationship and the persistence of aggressive advertising and sale promotion strategies all make for problems. Many marketers look to RM merely as the next stage in the manipulation of consumer data. However, an approach which relies heavily upon direct mail and database marketing, as a "blunt" instrument to reach large numbers of customers will detract from a relationship approach (Dibb and Meadows 2001).

The kind of relationship desired, which refers to anything from a full-blooded long-term relationship to a one-off transaction, has to be dependent, on the one hand, on what the customer wants, and on the other, on how well the supplier can match that (Szmigin and Bourne 1998). Since companies and individual consumers act out of self-interest, it cannotmakesense to have an approach that rewards the supplier MAY NOT BE REPRODUCED WITHOUT PERMISSSION 
but not the customer. But for many companies, it is not easy to balance what are two potentially contradictory outcomes of the relationship - company profitability and customer satisfaction. When companies ask their customers for friendship and loyalty, often they do not give customers friendship and loyalty in return. So, how do companies follow through on the assertion that they value one-to-one relationships with their customers (Egan 2000)? Both sides of any transaction or relationship affect its nature and in a good relationship there should be a balance between giving and getting. Yet, a review of the literature on RM reveals a definitive tendency to focus on the seller's perspective to the neglect of the buyer's perspective (Sheth and Parvatiyar 1995; Barnes 1997). Hence, the development of RM practices, particularly in consumer markets, seems to suffer from several shortcomings (Grayson and Ambler 1999; Shrivastava and Kale 2003) because RM, as a concept, represents only a part of a broader issue: relationships.

Within industrial market research, relationships have been studied more in depth. According to the interaction approach (Håkansson 1982), the ideal relationship implies that both parties are positively committed. The analogy used is that of a marriage - an exclusive, enduring and personal relationship between two people, which forsakes all others (Tynan 1997). However, this kind of relationship is not usual in consumer markets, where this might be attractive for the supplier, but may not be so for the buyer, who is expected to make a commitment, which incurs the opportunity cost of fidelity (Szmigin and Bourne 1998). The majority of consumer relationships are not close and long-term; rather, they are distant and discrete (O'Malley and Tynan 2000). Hence, findings from industrial markets should not be uncritically applied in the context of consumer markets. The differences between the two domains range across (although not limited to) issues such as switching-costs, availability of alternatives, type and frequency of interactions, level of interdependency, underlying motives, relative size and the overall importance given to relationships. These differences have consequences on the patterns of buyer-seller relationships that exist in both markets and standardised practices are unlikely to be effective (Hibbard, Brunel, Dant and Iacobucci 2001). Indeed, in consumer markets in particular, the development of anything approaching loyalty and commitment is an almost impossible task (Pressey and Mathews 2000). Given this scenario, the objective for the supplier should not be the "marriage partner", but rather the "preferred friend" (Szmigin and Bourne 1998). Thus, it is important to re-consider what a relationship in a consumer market context means.

However, in these markets, the concept rarely is defined at all, constituting a "glaring omission" (Bagozzi 1995, p. 275). The literature often discusses activities the firm should engage in to develop, maintain and enhance relationships with customers. Assumed consequences of good relationships are often discussed as well (Strandvik and Liljander 1994). The term "relationship" is often used by practitioners to underpin a supplier's marketing activities based on the assumption that a relationship can be formed with any customer, in any situation (Blois 1997). But if the sine qua non of a relationship is interaction and if situations exist where consumers are not even aware they are participating, can this be called a relationship? This "consumer recognition" factor may be the prime driver to a relational approach. A relationship can only be said to truly exist if and when the customer says there is one, and not when the marketing department suggests that it may be beneficial to construct one (Egan 1999). If a firm repeatedly approaches a customer and the customer does not buy anything, at the end there is no relationship. Besides, not every exchange has the potential to grow into a relationship. The concept of customer retention (which (C) 2008 WESTBURN PUBLISHERS LTD.

MAY NOT BE REPRODUCED WITHOUT PERMISSSION 
includes loyalty programmes and database marketing) appears to have been equated with the establishment of customer relationships. However, it is not inconceivable that customers may be retained, often for very long periods, without a genuine relationship being present. Conversely, a customer may not purchase regularly from a firm but still perceive something of a relationship with that firm. It may even be that marketers are fooling themselves (Egan 2000). The result, where the concept is applied too broadly or where it is misapplied, is that valuable resources may be wasted, simply because the buyer does not want a relationship (Barnes 1997). Customer's interests should be at the heart of the equation and to ignore it might mean a new kind of marketing myopia. Clearly, this topic does not appear to be adequately covered in the literature to date and the customers' perspective remains the blind spot of relationships in consumer markets (Pels 1999).

\section{REASSESSING RELATIONSHIPS IN CONSUMER MARKETS}

This paper looks at the nature of relationships between customers and retailers, since RM studies strongly emphasise the behaviour of consumers or of firms, but not of both simultaneously. Several authors emphasise the importance of integrating both sides of the relationship. Fournier, Dobscha and Mick (1998, p. 343) refer that "the basic questions of whether, why and which forms consumers seek and value ongoing relationships remain largely unanswered". Sheth and Parvatiyar (1995, p. 256) advocate that "taking the consumer perspective and understanding what motivates consumers to become loyal is important". And Dwyer, Shurr and Oh (1987) recognised that buyer and seller investments in a relationship jointly determine relationship outcome. Accordingly, our main purpose is to discuss relationships in consumer markets taking both parties into consideration. Thus, our research emphasises the perspectives of both sides of a relationship. Moreover, the product/services involved and the market are considered. These dimensions may influence relationships both directly and indirectly and are partly overlapping. Next, we present a description of all categories. Our research framework is illustrated graphically in Figure 1.

\section{The product and market dimensions}

Product nature is represented in this model as a contextual factor that intermediates and explains the buyer-seller relationship. Each product-market may exhibit different levels of relationship-friendliness, since enhancing relationships is generally easier in high involvement contexts as opposed to low involvement ones (Pressey and Mathews 2000). Important elements include transparency and competition (which affects the number of actors, available choices, switching costs), physical distance between actors (direct and personal contact, interactivity intensity) and power balance (actor's active or passive roles). Also product categories characterised by high service components and customisation (Grönroos 2000) may help the formation of relationships. The context may not only alter the status quo, but also the actor's behaviour, according to their perception of it, as argued by Pels (1999).

\section{The seller dimension}

From the seller's point of view, a relational approach can be very costly. Competition develops cost pressures, generating mass production to the sacrifice of customisation, 
service and personal interaction. If individual consumers represent a small purchase volume, the cost of customer acquisition is marginal, and the cost of retention may, potentially, exceed it (Egan 2000). Where there are too many customers, managing communication tools, to interact with them may be easier said than done. If the perception of the environment points to a long-term orientation, the firm needs to actively plan relationship efforts (Ganesan 1994). Preliminary results of research show that relationship efforts can be classified according to five types: communication with customers, customisation of products according to their characteristics, differentiation between customers, personalisation degree and loyalty reward schemes. To develop this kind of strategy, marketers rely on resources and capabilities like technology, brand name, market knowledge and information, etc.

\section{The consumer dimension}

Not all customers wish to engage in close relationships with retailers and are necessarily willing participants in the RM strategies devised (Fournier, Dobscha and Mick 1998), nor are all equally receptive (Bendapudi and Berry 1997). The clients' receptivity to engage in relationships is believed to affect the success of relational strategies (Sheth and Parvatiyar 1995). Some product-market features may impact

FIGURE 1 Research framework

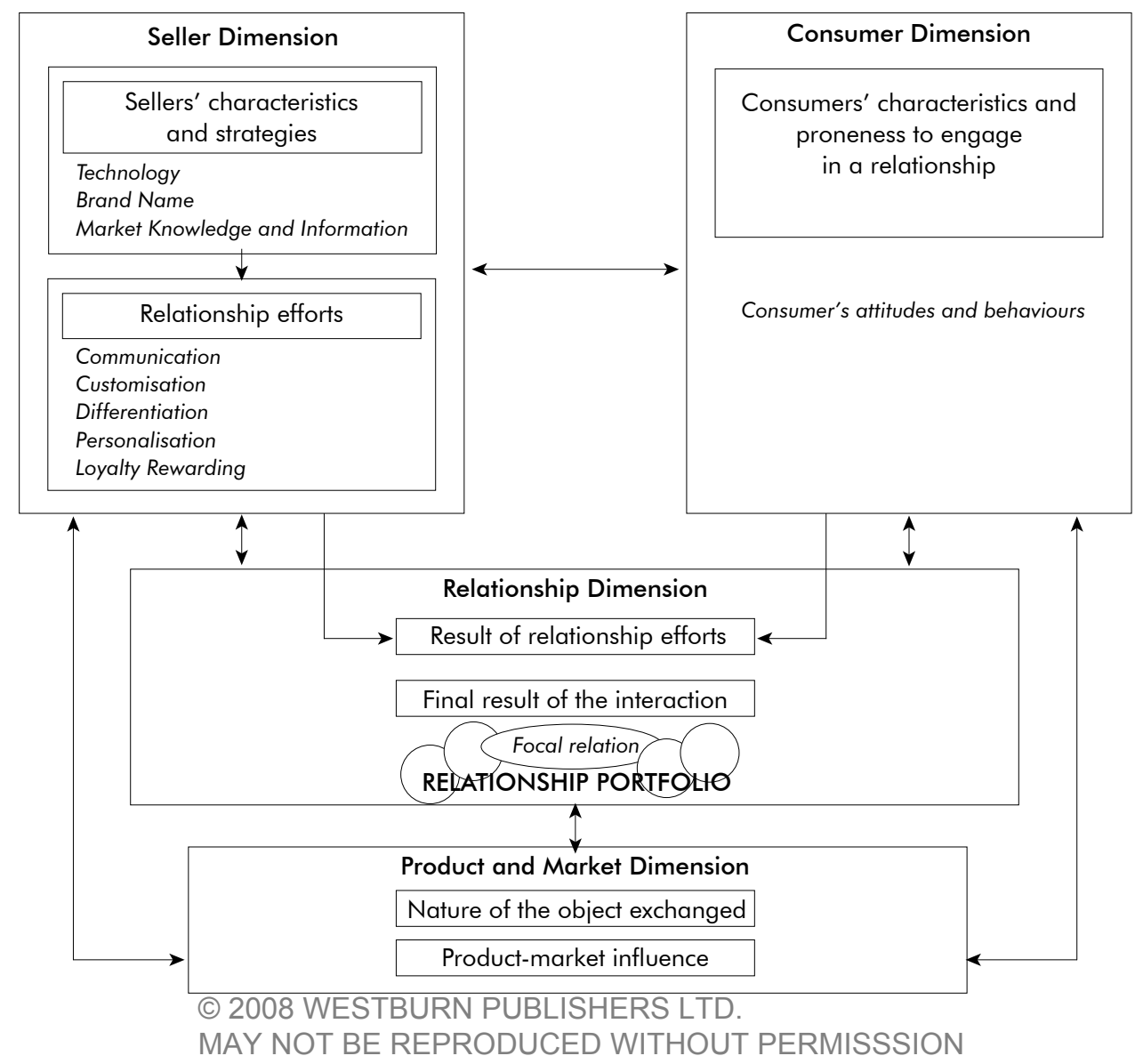


in this receptiveness. With reduced services, commoditised products, increased availability and reduced switching costs, consumers may not value relationships. Also situations when consumers play a passive role and interactive communication is lacking do not facilitate a relational environment (Pressey and Mathews 2000). According to their own competencies and perceptions, customers can be transactional in some situations and relational in others (Benamour and Prim 2000; Pels 1999). In purchases characterised by high risk perception and high salience, the customer may be seeking a relationship with the provider (Egan 2000).

\section{The relationship dimension}

Finally, the research framework will consider the result of the interaction process. This is the research crucial aspect: how are relationships in consumer markets? Relationships should be viewed as being diverse rather than adhering to one common format of development from arms-length to increasingly close relationships. In consumer markets, a customer can have simultaneous relations with several competing service providers and, over time, some of the relations will be dropped and others may be established. The same happens with firms: since it is neither possible nor profitable to create close, personal and long-term relationships with all consumers in all product markets, sellers also have to manage their relationships portfolio. Of course one may argue that consumer markets do not naturally supply a suitable climate for profitable long-term relationships. However, the point is not whether interaction may occur between firms and consumers, but to understand the different levels of interaction actors desire (Pels 1999), so that we are able to find something new and diverse but still, in some extent, probably "relational" about consumer-firm interactions.

These four analytical constructs have been integrated in order to develop a research arena for relationship studies in consumer settings, where we question whether a relationship is necessarily the preferred state from the customer's perspective or if this is only in the mind of the seller. Adopting a different set of lenses suggests the following question - what is the customer's definition of a relationship? According to Czepiel (1990) a relationship consists of a mutual recognition of some special status between exchange partners. A consumer may wish to engage in quite different types of relationships with different providers or with firms in different industries. This leads the debate to other related issue - the identification of customers who are more likely to develop relationships. Relationship prone consumers may see a retailer's efforts through more rose-coloured glasses, but some customers may even view it as intrusive and reject it. What one customer may consider a close, friendly relationship, others will find stifling and unnecessary (Barnes 1997). Yet, few authors have considered the question of what type of customers are expected to be interested in, or more prone to form a relationship with their company.

In this study, we define consumer relationship proneness as a consumer's tendency to engage in relationships with providers of a particular product category. According to Barnes (1997), in some situations a genuine relationship can't be formed because customers do not want one or because the circumstances surrounding the firm's interaction with its customers are not conducive. In fact, relationships both drive and are driven by the context in which they take place (Fournier, Dobscha and Mick 1998). The actor's choices seem to depend on both the environment in which they operate in and their perception of it (Lindgreen and Pels 2002). Therefore, we suggest product category as a precursor of this "relationship-friendliness" (Christy, Oliver and Penn 1996, p.185). Also the more or less functional orientation of (C) 2008 WESTBURN PUBLISHERS LTD. MAY NOT BE REPRODUCED WITHOUT PERMISSSION 
FIGURE 2 Consumer proneness matrix

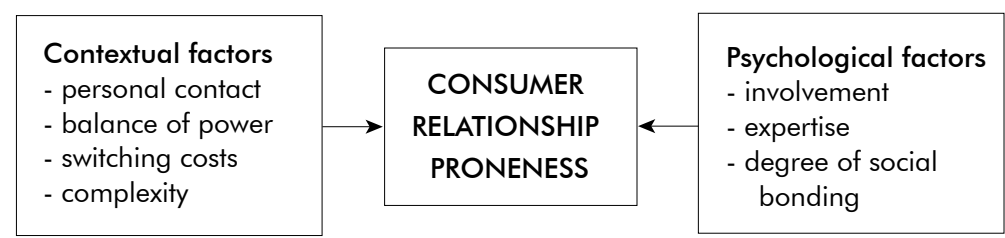

the client seems to explain the different types of relationship desired (Benamour and Prim 2000). Altogether, this would explain, for instance, why the same client expresses reluctance to develop an intimate relationship with certain providers, while developing it with others. To further understand what elements influences consumer relationship proneness, it is important to discuss the relation between contextual factors and psychological factors. Lindgreen and Pels (2002) scheme helped us define our matrix, illustrated in Figure 2.

\section{RESEARCH METHODOLOGY}

We developed a comparative case study analysis (Eisenhart 1989; Ragin 1987). Each case consists of a firm, operating in consumer markets, which develops a relationship approach towards its clients. The empirical research was conducted in service contexts given its inherently relational nature (Grönroos 2000) and since much of the current understanding of RM is due to advances in these settings (Lindgreen and Pels 2002). The case selection achieves illustrative situations following Bowen's (1990) service typology: (i) high contact, customised, personal service (Case 1: Banking services); (ii) moderate contact, semi-customised, non-personal service (Case 2: Mobile communication services); and (iii) moderate contact, standardised, semi-personal service (Case 3: Bookstore services). Also the markets selected are highly competitive and transparent to prevent constraints due to limited choice or information. Under these conditions, all firms considered in the study developed relationship strategies to differentiate themselves from competitors.

Research collected data both from the seller and the buyer side of the relationship: on one hand, the efforts carried out by firms; and on the other hand, the proneness of customers concerning those intended "relational" efforts. Semi-structured interviews with key informants were chosen to "measure" the "seller dimension", while focus groups discussions were the research instrument selected for the "consumer dimension". The intention was to gain new insights about what is the relationship to the customer and to compare it with the firm's perspective. The interviewees on behalf of the firms were selected on the basis of their experience and involvement in RM strategies. They were all senior and middle managers. The interviews included questions about the following issues: customer data collection and analysis; the way it is used to build and manage relationships; and the critical factors of success. The focus groups were selected from the chosen firms' client database and structured so as to gain an adequate cross-section of client types using a balanced set of criteria (e.g. gender, regular/non regular customers), whilst maintaining homogeneity (based on age and social background) as directed by Malhotra (2004) and Carson et al. (2001). Participants had never participated in previous research as suggested by (C) 2008 WESTBURN PUBLISHERS LTD. 
Malhotra (2004). Discussions involved a total of 18 participants, divided up into three sessions of 6 participants each, according to the concept of "mini-focus group" (Fern 2001). They were deliberately not told that the elements extracted would concern the concept of "relationship", so that they would highlight them without being prompted. Discussions concerned their relation to the firm and how different incidents affected it, earlier and parallel relationships.

The following section shows the main results. The four areas identified above (seller, consumer, product-market and relationship dimensions) will be used in the analysis, as well as the consumer proneness matrix.

\section{THE CASE STUDIES' MAJOR FINDINGS}

\section{Case 1: banking services relationships}

high contact, customised, personal service

\section{Product and market dimensions}

According to Haaff (1989), financial services fulfil the conditions of interpersonal relationship marketing. There may be a perception of uncertainty on the part of the customer, not only from a technical point of view, but also because of the possibility of asymmetric information. Customers can be vulnerable to opportunistic behaviour, but it is also possible that dependence occurs, due to the scarcity of alternatives (or at least perceived as better alternatives) or to pure inertia. In such a situation, it is clear how important the development of a relationship can be not only to the bank but also to the customer.

\section{Seller dimension}

This bank believes that, to build relationships successfully with customers, two attributes are vital: the bank's reputation and the value of products on offer. Customers tend to believe that the bank knows them and their contact with the organisation must reinforce this. Relationship building communication must be perceived to be personal, and as such the bank doesn't adopt a hard selling approach. That explains why, although direct mail is used, outlets remain the primary point of contact. Cross selling is also used to encourage customers to buy more products and strengthen their connections with the bank. The focus is on understanding the value of each customer. The bank looks for events and triggers in customer's lives (such as buying a house or having children) to drive RM and to enhance value offered. While the bank appreciates the value of data, it is also aware of the cost of obtaining it, so that every item held should have a clear value according to a profitability model, concentrating resources upon the "best" segments. In this context, we came across a remarkable statement: with privileged private banking customers, "...the bank does not practice RM; we develop relationships."

\section{Consumer dimension}

The discussions with the customers concerned their relation to their main bank and how different incidents have influenced it; earlier and parallel minor bank relationships; and the beginning and possible end of each relationship. Some customers were satisfied with their main bank and even recommend it, considering it a "relationshin" Minor negativeincidents-were ngt enough to make them change 
or search for another. Therefore, reasons for changing bank (although keeping an account in their old bank) have generally to do with not getting a housing loan from their own bank or some other kind of external change (e.g. change of employment). Usually, they have a privileged contact person, whom they trust and talk frequently to. Conversely, other customers do not have any contact with the bank personnel and prefer to relate at a distance. They seek information and choose the best alternative, demonstrating no loyalty. They find some bank initiatives, such as promotional mailings and phone calls rather pushing, impersonal, intrusive and even harmful. They feel forced into relationships through wired incentives or punishments and, since they feel they don't receive the deserved attention, tend to react in the same way.

\section{Relationship dimension}

Even if banks are convinced about the value of the relationship approach, it is far from clear whether all customers feel the same. Banks seem to only show interest in developing some kind of personal interaction when they perceive some obvious benefit (e.g. with a few valuable customers, like private banking ones). In this situation, context conditions seem to outweigh individual choices: banks are profiting from the power they hold and build switching barriers, but their customers are not satisfied. In contextual terms, this (in) balance of power, switching costs perceived and technical complexity runs against the strong involvement present and the need for personal contact by the customer. Customers considered valuable by the bank benefit from personal service, which enables mutual disclosure of information and is the basis for higher relationship levels. Those customers who feel mistreated develop nothing more than a "forced" relationship with their bank.

\section{Case 2: mobile telecoms relationships}

moderate contact, semi-customised, non-personal service

\section{Product and market dimensions}

This is a fiercely competitive, dynamic and highly saturated market context. The mobile telecommunications market is a good example of a market where the core product has become a commodity. In such conditions, it is extremely important to retain existing customers. One of the major challenges for the companies is to identify the factors that appeal to customers' willingness to switch between operators. The lack of perceived differences indicates no traditional barriers to prevent customers from switching. Offered services cannot be described as truly interactive: customers search and retrieve information, but there are few instances where they enter into an active dialogue with the firm. Switching behaviour is often based on word-ofmouth from peers. The usefulness of mobile services depends on other users using it rather than the attributes of the service. Extrinsic attributes (network size, fashion, status) are more important to create customer value than the intrinsic attributes of the service (technical specifications) (Liljander et al. 2004).

\section{Seller dimension}

These companies attempt to achieve the ultimate attribute of RM, i.e., to establish long-term relationships with their customers. Companies are combining data mining (background information on customer spending and usage patterns) with personal 
communication (to find out what problems customers have encountered and what information they need in order to fully enjoy the service) in order to reduce switching behaviour. However, this is easier said than done: the company doesn't know most of its clients, since they have no obligation to register and identify themselves. Moreover, the company has the notion that customers are not loyal "like in a bank". Instead, since quality perceptions between companies are similar, the losses incurred by switching are perceived to be minimal and reduced to the "network effect". As such, the company tries to develop switching barriers, such as annual card payments and loyalty programmes. The company usually prizes loyalty by offering special tokens regularly. Also, firms are investing in this field as a source of differentiation. While less valuable customers access a standard supporting service, the more valuable segments benefit from a highly personal one. The idea is to make customers feel that they are special, not only on a merely commercial level, but also on a personal level.

\section{Consumer dimension}

Unlike financial services, the perception of uncertainty and the scarcity of alternatives are not among consumers' problems. Assurance is of less importance and security is taken for granted. Furthermore, customers seem to be getting more out of loyalty schemes than telecoms, despite the growing resources committed in customer loyalty. Some customers show loyalty based on habit or inertia. Although they find change easy, the status quo seems more appealing: offers are undifferentiated, so no better off, too much bother. They are not naïve about telecoms' intentions. They contact the call centre expecting problems to be solved; too much "talk" would be "boring". Conversely, responsive customers value loyalty programmes and compare alternatives, but stick with the same firm as long as opportunity costs are not significant.

\section{Relationship dimension}

Unlike the previous case, here it is the seller that wants to develop a close relationship based on cooperation and commitment, while the buyer acts out of self-interest and on calculations of expected returns to him/herself relative to alternative offers, showing no loyalty. The only kind of loyalty present here is based on habit or inertia, which is not real loyalty, since the reasons for patronage are not positive. The level of involvement is low, the expertise required is minimum and only extrinsic attributes are important. Also, in contextual terms, switching costs are not significant enough to inhibit customer mobility, offers are perceived as undifferentiated and easy to compare, there is no personal contact and the balance of power favours the customer, who exhibits low relationship proneness.

\section{Case 3: retail services relationships}

\section{moderate contact, standardised service}

\section{Product and market dimensions}

According to Egan (1999), retailing appears to be an industry where relational strategies can be exploited. Indeed, many authors relate the widespread use of store loyalty cards as evidence of the take up of RM in the field. However, this is a fast moving consumer setting (Pressey and Mathews 2000), where price or convenience of location may be stronger motivators than loyalty schemes and other relational 
efforts. Moreover, the cost of customer acquisition is marginal, and the cost of retention may, potentially, exceed the cost of acquisition or the reward schemes introduced by retailers.

\section{Seller dimension}

The high street bookstore considered was the first multinational to introduce the concept of "supermarket" in the sector. Besides books, the store sells a wide variety and a large selection of CD, DVD, electronic devices and so on. The store is essentially a large faceless organisation with a high degree of influence over the consumer and is relatively low-staffed. However, the service provides expert advice and handles complaints efficiently, although in a largely impersonal way. The store runs a loyalty card scheme, using price incentives to retain customers. However, there are costs implied: consumers have to pay a small amount in order to receive a card (it is only free during the first year). There is also a social aspect involved in visiting the store, which intents to develop the potential for an emotional link.

\section{Consumer dimension}

Consumers like to shop at different stores in order to get the best prices or to take advantage of special offers. Although the bookstore was their favourite, they want to try different ones, without restrictions, however good that may be. They consider loyalty the "first choice" in shopping, rather than being committed to the seller. Financial incentives are not an effective way to engender loyalty. Loyalty cards are appreciated, but only if they don't imply any commitment. In fact, customers hold several loyalty cards and use them, but still find more value in a repertoire of relationships or "good friends" from which they choose. Others see little value in developing a relationship, and adopt a transactional mode, making their choices considering price and always comparing alternatives. Often they stop using the card once the benefit has been achieved. Also customers don't develop extensive relationships with personnel beyond the point of sale, but their professionalism is recognised. The wide range of offers and the self service are also appreciated.

\section{Relationship dimension}

Not all consumers value a relationship with a store as encapsulated by owning its card and would prefer a more transactional approach. They don't wish to feel "tied" to a particular store, but are prepared to accept a card if there is a transactional benefit, typically a price discount. Consumers may as well choose to hold a number of cards and build up points over a range of stores in their search for variety. When this occurs, the balance of power in the relationship changes: consumers get the benefit of discounts without having to make a commitment to a single retailer; and the retailers get an incomplete database so lose the benefits of customer profiling. Again, the level of involvement is low, the expertise required is minimum, switching costs are not significant and contacts are strictly professional. However, here the "relationship" seems to be not so poorly managed as in the previous cases, since the balance of power is not so different and both parties adopt a transactional approach. 


\section{DISCUSSION OF RESULTS}

This article introduces a research framework and a consumer proneness matrix. The models are simple, but integrate the role of the environment and a dyadic approach to consumer markets. From this framework, three case studies were developed.

The case studies suggest that some consumers are looking for close relationships and may actively participate in the firm's activities, while others have no desire to engage in one and could not care less about their providers. Dwyer, Shurr and Oh (1997) term these cases as "buyers supported relationships" and "sellers supported relationships", respectively. Individual consumers act mostly out of self-interest and are, in the main, promiscuous in the relationships they establish. For reasons of time, location or others, customers are "polygamous" in their shopping habits. Many customers do not want a long-term relationship, but low prices and convenience. They may not all want or need a relationship, their potential benefits may not be equally considered worthwhile, and different people may prefer different kinds of relationships. In this case, sellers are relationship-seekers who try to seduce freerider buyers with additional benefits and try to convince them of the benefits of establishing relationships. Often, they fail, because the buyer only seeks to satisfy a generic need and refuses to get involved. Still, where there is no alternative and no perceivable difference, the consumer may just as well stick with the same provider. However, having a large number of customers who feel "trapped" is likely to lead to negative word of mouth, less ability to cross-sell and other negative outcomes. Loyalty schemes have been promoted and viewed as a method of achieving real differentiation and competitive advantage, with the aim of establishing long-term relationships between the firm and the customer, creating a sense of belonging. However, it seems that these loyalty schemes amount to little more than "money off next purchase discounts" (Christy, Oliver and Penn 1996), developing nothing more than a "forced" relationship with the consumer, whereby the benefits appear to be balanced in favour of the seller. It might be that the best loyalty scheme is to offer more value, as defined by its target customers. However, no conclusion on the "right" strategy to implement is straightforward, since different situations are likely to coexist with different consumers, making it hard to establish a general pattern.

\section{CONCLUSION}

This paper discusses relationship marketing (RM) and the nature of buyer-seller relationships in consumer settings. We argue that the application of the concept to consumer markets requires care and should consider the perspectives of both sides of a relationship, the product/services involved and the market context. Accordingly, we submit that relationships should be viewed as being diverse rather than adhering to one common format of development from arms-length to increasingly close relationships.

The contributions of this study are twofold. First, it critically examines theories underlying RM, developing a dyadic model where both parties are taken into consideration, fulfilling an identified gap in the literature, and introducing consumer proneness as a driver of buyer-seller relationships in consumer markets. Second, on a managerial level, we hope that knowing the effects of RM strategies and identifying those buyers who are most prone to relationships will provide guidelines for firms to 
fine-tune their relational efforts.

The results presented indicate that there is much to be learned about the interaction between the consumer and the provider. We show that marketers must guard against assuming that a relationship is what all customers' want or need. The results show that relationships are not universal. This supports the idea that different relationship levels exist within the widespread domain that makes up the consumer market. As such, markets should be segmented according to the type of relationship the customer desires. The challenge to marketers is to identify those circumstances that are most conducive to the establishment of relationships. Any solution based on an overall-unique exchange model runs the risk of myopia. The need for further, more comprehensive analysis of the data is obvious and quantitative instruments could be developed to uncover more interesting findings. Also while we are mainly discussing services, we suggest that the thinking here may not be restricted to this sector and that more in-depth knowledge of the nature of relationships in other contexts is needed, like business markets or industrial goods. This area is in its first stage of development and we hope that this and further extended research will open new doors to deepen our understanding of relationships in marketing.

\section{REFERENCES}

Bagozzi, R. P. (1995), "Reflections on relationship marketing in consumer markets", Journal of the Academy of Marketing Science, Vol. 23, No. 4, pp. 272-277.

Barnes, J. G. (1997), "Closeness, strength, and satisfaction: examining the nature of relationships between providers of financial services and their retail customers", Psychology and Marketing, Vol. 14, No. 8, pp. 765-790.

Benamour, Y. and Prim, I. (2000), "Orientation relationnelle versus transactionelle du client: development d'une échelle dans le secteur bancaire français: une etude exploratoire”, Centre de Recherche DMSP, Cahier $\mathrm{n}^{\circ} 279$.

Bendapudi, N. and Berry, L. L. (1997), “Customer's motivation for maintaining relationships with service providers", Journal of Retailing, Vol. 73, No. 1, pp. 15-37.

Berry, L. L. (2002), "Relationship marketing of services - Perspectives from 1983 and 2000", Journal of Relationship Marketing, Vol. 1, No. 1, pp. 59-77.

Blois, K. J. (1997), “When is a relationship "A Relationship"?”. In: Relationships and Networks in International Markets, Pergamon: Elsevier Science, pp. 53-64.

Bowen, J. T. (1990), "Development of a taxonomy of services to gain strategic marketing insights", Journal of the Academy of Marketing Science, Vol. 18, No. 1, pp. 43-49.

Buttle, F. A. (1996), Relationship Marketing: Theory and Practice, London: Paul Chapman Publishing.

Carson, D. J., Gilmore, A., Perry, C. and Gronhaug, K. (2001), Qualitative Marketing Research, London: Sage Publications Ltd.

Christy, R., Oliver, G. and Penn, J. (1996), "Relationship marketing in consumer markets", Journal of Marketing Management, Vol. 12, No. 1, pp. 175-187.

Czepiel, J. A. (1990), "Service encounters and service relationships: Implications for Research", Journal of Business Research, Vol. 20, No. 1, pp. 13-21.

Dibb, S. and Meadows, M. (2001), "The application of a relationship marketing perspective in retail banking", The Services Industries Journal, Vol. 21, No. 1, pp. 169-194.

Dwyer, F. R., Shurr, P. H. and Oh, S. (1987), “Developing buyer seller relationships”, Journal of Marketing, Vol. 51, No. 2, pp. 11-28.

Eisenhardt, K.M. (1989), "Building theories from case study research", Academy of Marketing Review, Vol. 14, No. 4, pp. 532-550. 
Egan, J. (1999), "Relationship marketing: across the retail spectrum”, Middlesex University Discussion Paper Series.

Egan, J. (2001), "Throwing the baby out with the bathwater?", Marketing Intelligence and Planning, Vol. 19, No. 6, pp. 375-384.

Egan, J. (2003), "Back to the future: divergence in relationship marketing research", Marketing Theory, Vol. 3, No. 1, pp. 145-157.

Håkansson, H. (1982), International marketing and purchasing of industrial goods: an interaction approach, Chichester, England: John Wiley and Sons.

Harker, M. J. and Egan, J. (2005), Relationship Marketing, London, UK: Sage Publications.

Fern, E. (2001), Advanced Focus Group Research, Thousand Oaks, CA: Publications Ltd.

Fournier, S. M., Dobscha, S. and Mick, D. G. (1998), "Preventing the premature death of relationship marketing", Harvard Business Review, Vol. 76, No. 1, pp. 42-48.

Ganesan, S. (1994), "Determinants of Long-Term Orientation in Buyer-Seller Relationships", Journal of Marketing, Vol. 58, No. 2, pp. 1-19.

Grayson K. and Ambler, T. (1999), "The dark side of long-term relationships in marketing services", Journal of Marketing Research, Vol. 36, No. 1, pp. 132-142.

Grönroos, C. (2004), "The relationship marketing process: communication, interaction, dialogue, value", Journal of Business and Industrial Marketing, Vol. 19, No. 2, pp. 99-113.

Grönroos, C. (2000), Service Management and Marketing: a Customer RelationshipManagement Approach $2^{\text {nd }}$ Edition, Chichester, England: John Wiley and Sons.

Grönroos, C. (1990), "Defining marketing: a market-oriented approach”, European Journal of Marketing, Vol. 23, No. 1, pp. 52-60.

Gummesson, E. (2004), "Return on relationships (ROR): the value of relationship marketing and CRM in business-to-business contexts", Journal of Business and Industrial Marketing, Vol. 19, No. 2, pp. 136-148.

Gummesson, E. (2002), Total Relationship Marketing, Oxford: Butterworth-Heinemann / Chartered Institute of Marketing.

Haaff, P. (1989), Top quality: a way of life in distinguished papers: Service quality in the 1990s. NY: St. John's University Business Research Institute, World Future Society.

Håkansson, H. (1982), International marketing and purchasing of industrial goods: an interaction approach, Chichester, England: John Wiley and Sons.

Harker, M. J. (2004), "Relationship marketing: concepts from customers". Proceedings of the 12th International Colloquium in Relationship Marketing, Hamilton: New Zealand.

Harker, M.J. (1999), "Relationship marketing defined? An examination of current relationship marketing definitions", Marketing Intelligence and Planning, Vol. 17, No 1, pp. 13-20.

Hibbard, J., Brunel, F., Dant, R. and Iacobucci, D. (2001), "Does relationship marketing age well?”, Business Strategy Review, Vol. 12, No. 4, pp. 29-36.

Jackson, B. (1985), Winning and Keeping Industrial Customers, Lexington, MA: Lexington Books.

Liljander, V. and Roos, I. (2002), "Customer-relationship levels - from spurious to true relationships", Journal of Services Marketing, Vol. 16, No. 7, pp. 593-614.

Liljander, V., van Riel, A. C. R, Lemmink, J. and Streukens, S. (2004), "Boost customer loyalty with online support: the case of mobile telecoms providers", International Journal of Internet Marketing and Advertising, Vol. 1, No. 1, pp. 4-23.

Lindgreen, A. and Pels, J. (2002), "Buyer-seller exchange situations: four empirical cases", Journal of Relationship Marketing, Vol. 1, No. 3-4, pp. 69-93.

Malhotra, N. (2004), Marketing Research, An Applied Orientation, Prentice Hall: Pearson Education International.

Mattsson, L. G. (1997). Relationship marketing in a network perspective. In: Gemunden, H. G., Ritter, T. and Walter, A. (eds.), Relationships and Networks in International Markets, Oxford: International Business and Management Series, Elsevier Science Ltd, pp. 37-47.

Möller, K. and Halinen, A. (2000), "Relationship marketing theory: its roots and directions", Journal of Marketing Management, Vol. 16, No. 1-3, pp. 29-54. 
O’Malley, L. and Tynan, C. (2000), "Relationship marketing in consumer markets: Rhetoric or Reality?", European Journal of Marketing, Vol. 34, No. 7, pp. 797-815.

Palmer, A. and Bejou, D. (1994), "Buyer-seller relationships: a conceptual model and empirical investigation", Journal of Marketing Management, Vol. 10, No. 7, pp. 495-512.

Pels, J. (1999), “Exchange relationships in consumer markets?”, European Journal of Marketing, Vol. 33, No. 1-2, pp. 19-37.

Pressey, A. D. and Mathews, B. P. (2000), "Barriers to relationship marketing in consumer retailing", Journal of Services Marketing, Vol. 14, No. 3, pp. 272-286.

Ragin, C. C. (1987), The Comparative Method: Moving Beyond Qualitative and Quantitative Strategies, Berkeley, Los Angeles, London: University of California Press.

Rao, S. and Perry, C. (2002), "Thinking about relationship marketing: where are we now?", Journal of Business and Industrial Marketing, Vol. 17, No. 7, pp. 598-614.

Sheth, J.N. and Parvatiyar, A. (2000), Handbook of Relationship Marketing, Thousand Oaks, CA: Sage Publications, Inc.

Sheth, J. N. and Parvatiyar, A. (1995), "Relationship marketing in consumer markets: antecedents and consequences", Journal of the Academy of Marketing Science, Vol. 23, No. 4, pp. 255-271.

Shrivastava, S. and Kale, S. H. (2003), "Philosophising on the elusiveness of relationship marketing theory in consumer markets: a case for reassessing ontological and epistemological assumptions”, Australasian Marketing Journal, Vol. 11, No. 3, pp. 61-72.

Szmigin, I. and Bourne, H. (1998), "Consumer equity in relationship marketing", Journal of Consumer Marketing, Vol. 15, No. 6, pp. 544-557.

Zolkiewski, J. (2004), "Relationships are not ubiquitous in marketing", European Journal of Marketing, Vol. 38, No. 1-2, pp. 24-29.

Zolkiewski, J. and Lewis, B. (2003), "An assessment of customer service in B2B relationships: a literature review and methodological issues", Proceedings of the $19^{\text {th }}$ Annual IMP Group Conference, CD-ROM ed., Lugano: Switzerland.

\section{ABOUT THE AUTHORS AND CORRESPONDENCE}

Teresa M. Fernandes is a Follow Researcher of Marketing at University of Porto, Faculty of Economics. She is PhD student in Business Management, University of Porto, Portugal and has a Master of Science in Business Administration, Oporto Management School, Portugal. Her main research focus is on consumer relationships.

Corresponding author: Teresa M. Fernandes, PhD student, Faculdade de Economia, Universidade do Porto, Rua Dr. Roberto Frias, s/n, 4200-464 Porto, Portugal.

$\mathrm{T}+351918373725$

F +351225505050

E tfernandes@fep.up.pt

João F. Proença is Professor of Marketing at University of Porto, Faculty of Economics; Portugal. He has a PhD in Business Management, University of Porto and a Master of Science in Marketing, Instituto de Empresa, Madrid, Spain. His main research focus is on business relationships, particularly business-to-business service marketing. $\mathrm{He}$ has published in a number of journals including the International Journal of Bank Marketing, the Journal of Customer Behaviour, the Portuguese Journal of Management Studies, the Service Business - An International Journal and in the International Review on Public and Non Profit Marketing. 
João F. Proença, Lecturer in Marketing, Faculdade de Economia, Universidade do Porto, Rua Dr. Roberto Frias, s/n, 4200-464 Porto, Portugal.

T +351934147470

$\mathrm{F}+351225505050$

E jproenca@fep.up.pt 